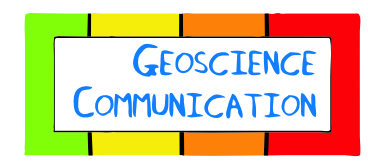

\title{
Using geosciences and mythology to locate Prospero's island
}

\author{
Tiziana Lanza \\ Istituto Nazionale di Geofisica e Vulcanologia (INGV), Rome, Italy \\ Correspondence: Tiziana Lanza (tiziana.lanza@ingv.it) \\ Received: 28 February 2020 - Discussion started: 30 April 2020 \\ Revised: 7 January 2021 - Accepted: 19 January 2021 - Published: 17 March 2021
}

Abstract. The Tempest, the last work entirely attributed to William Shakespeare, has been subject to many studies and interpretations, ranging from adventure and Shakespeare's biography to colonialism and the cultural revolution, and is studied in this paper in the context of naturally occurring hazards. The play tells the story of a magician, Prospero, and his daughter who are shipwrecked on an unknown island where they encounter strange creatures and beings. But is it a fantastic island or was the author inspired by real places? Literary scholars proposed several hypotheses through the years, based on historical sources. Here, we analyse the play in the light of geosciences and mythology supporting the hypothesis that the playwright was inspired by the Mediterranean. Our goal is not to identify the island but rather to examine the various geographical and philosophical-political factors that may have influenced Shakespeare's literary creation. Nevertheless, some verses in the play suggest volcanism, placing the island in the Sicilian sea. This underlines once again how deep the playwright's knowledge of Italy was. It also suggests that this part of the Mediterranean was known, at the time of Shakespeare, as the theatre of phenomena originated in the volcanism of the area. One implication is that he could have used historical sources, still unknown and precious, to reconstruct geological events that occurred off the Sicilian coast.

\section{Introduction}

A new trend towards the reunification of the two main streams of culture, the humanistic and the scientific, is becoming more evident year by year. Scientists and artists cocreate projects to address issues of societal importance in a holistic way and to improve science communication. Earth scientists, in particular, are familiar with studying historical records and literary accounts, mythology and story telling in addition to geo-archaeological evidences to reconstruct a timeline of historic catastrophic events such as earthquakes, volcano outbreaks, floods, storms, etc. Even with the evolution of technology that has brought geoscientists new, sophisticated methods of investigation, modern seismology cannot do without a deep immersion into historical and literary accounts for calculating, for instance, the return period of an earthquake. The Istituto Nazionale di Geofisica e Vulcanologia (INGV) in Italy contributed significantly to this by collecting, in an original volume, the ancient earthquakes in the Mediterranean area up to the 10th century (Guidoboni et al., 1994). Another important contribution is the catalogue of strong Italian earthquakes (Boschi et al., 1995). The catalogue is kept up to date and has recently been extended to the large earthquakes (6.0-6.9 magnitude) of the Mediterranean area (Guidoboni et al., 2019). Collecting literary accounts, ranging from historical sources until the most recent chronicles, also allows us to document minor, little details that might help us to better understand an earthquake of the past in terms of magnitude, intensity and social impact.

Combining historical, literary, geo-mythological and archaeological accounts play a fundamental role in reconstructing past volcanic events and their impacts on society and environment. In the renown case of the 79 AD Vesuvius eruption that destroyed Pompeii and Herculaneum, the accounts of Pliny the Younger, a Roman administrator and a poet, who witnessed and documented the catastrophic event in a letter to Tacitus (Jones, 2001), helped geoscientists to reconstruct several earthquakes that preceded the event. The effects are still visible in several buildings in Pompeii and Villa Regina. Observing the event from Miseno at a distance of $21 \mathrm{~km}$, Pliny described the eruptive cloud as a "Mediterranean pine". During the morning of the second day, he observed the development of pyroclastic flows descending down the flanks 


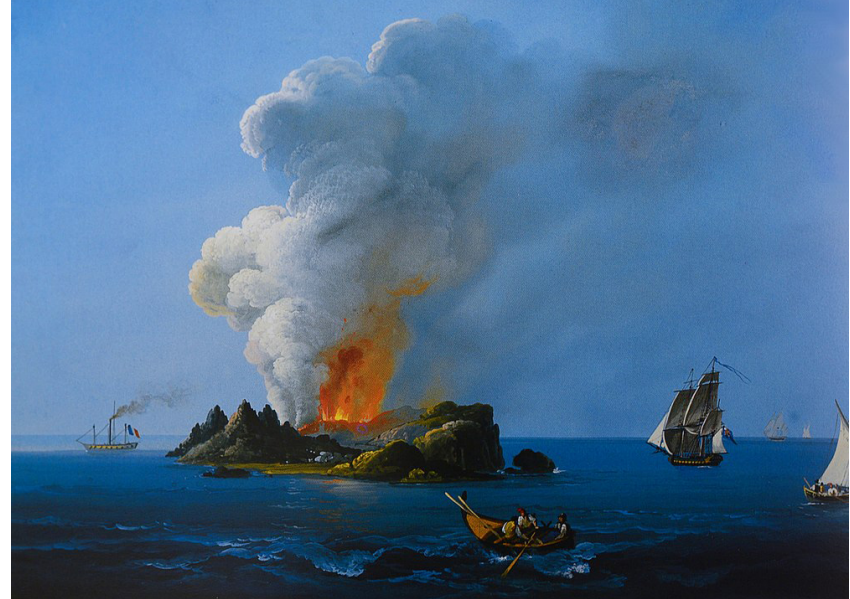

Figure 1. The Ferdinandea island (Graham Island) in a painting by Camillo de Vito in 1831. Source: Wikipedia.

of Vesuvius and flowing on the sea. The description fits well with the geologic record of the eruption (Giacomelli et al., 2003).

Some events remain difficult to reconstruct because of a lack of observers. Mercalli (1883) asserts that there are only few records about volcanic eruptions at sea, since the phenomena at the time could be witnessed predominantly by sailors. Mercalli (1883) reports some episodes that happened in the Sicilian Channel, including the most popular Ferdinandea island (Graham Island) emerging from the sea in 1831 (see Figs. 1 and 5.). As we will show later, we are stunned by the way Shakespeare describes a natural phenomenon so similar to the ones described by Mercalli in his book which was published 2 centuries later.

\section{Methodology}

In this paper, we will do the opposite of what was previously described. We will use geosciences and geo-mythology to better understand a work of art renown worldwide as a masterpiece of William Shakespeare (hereafter WS) - The Tempest (Shakespeare, 1986).

Although we consider the WS authorship question an important aspect to address for a better understanding of his works, we will not discuss it here but we refer the reader to a recent publication that considers it from a scientific perspective (Leigh et al., 2019). We are also aware that considering the play in the light of the early modern knowledge and the way it circulates is important, although do not guarantee a more precise interpretation of the verses. We cannot be sure of which texts WS used to build his own knowledge. At the same time, it is debated whether WS knew classic languages sufficiently well to read the original sources since he was deeply schooled in the classics (Werth, 2002; Stritmatter, 2017).
Then, since there are many interpretation of The Tempest and, at the same time, the biography of WS is also subject to much controversy, we take the approach that the text can be accepted as reliable source. The interpretation of the verses, although difficult, can enlighten us with respect to the possibility that WS was truly inspired by real places and by natural phenomena. Here, we propose that WS took inspiration mainly from literature that directly originates from natural phenomena. In this way, the discipline of geo-mythology is based on the idea that myths and legends have their origin in the natural world and can be seen as a source of natural knowledge based on the observation of physical evidence. Early human civilizations used myths to organize and convey information to transmit the wisdom necessary to live in harmony with and survive in nature (Lanza and Negrete, 2007). The term was originally conceived as the geological application of the term "Euhemerism", from the Sicilian philosopher, Euhemerus (300 BC), who held the belief that the gods of mythology were simply deified mortals. Then, this new discipline is based on the idea that some myths and legends can be explained in terms of actual geological events witnessed by various groups of people (Vitaliano, 1973).

In the present study, it is fundamental that the route traced in The Tempest by the court party is similar to that traced by Aeneas in the Aeneid. This cannot be relegated to the background, as many have done by embracing the trend of interpretations based on the Bermuda hypothesis. In fact, the journey that the characters make, from a geophysical and naturalistic point of view, is a journey into the land of volcanoes.

To sum up, it is our intention to analyse, in the play, all that is connected to a real location in terms of an environmental and geophysical asset, using sources from geoscience studies, history and others. We are encouraged in this by the rich naturalistic vocabulary present in the play, with terms identifying specific flora and fauna and even geological and geophysical features (see Table 1).

After introducing the play and also referring to the period of the English Renaissance, we will address one of the unsolved questions among literary scholars which concerns the location of Prospero's island, first, taking into consideration the Bermuda hypothesis and, second, the possibility of placing the island into a Mediterranean contest.

Finally, taking into account both the geology off the Sicilian coast and the mythology of the Mediterranean area, we propose an interpretation of the verses in a new and, so far, never before considered perspective.

\subsection{Shakespeare and volcanoes}

Despite the numerous publications, books and academic articles on Shakespeare and science (Clark, 2005; Mazzio, 2009; Spiller, 2009; Falk, 2014), and apart from the books on the way WS deals with storms and weather (Jones, 2016; Chiari, 2019), only a few studies address WS's possible interest in 
Table 1. The terms related to the flora and fauna, geology and the troposphere as collected by the author from the play. In the last column are some geophysical phenomena, as suggested from the verses analysed in the paper.

\begin{tabular}{|c|c|c|c|c|}
\hline Flora & Fauna & Geology & Troposphere & $\begin{array}{l}\text { Other geophysical } \\
\text { phenomena }\end{array}$ \\
\hline Pine & Wolves & Deep nook & Storm & St Elmo's fire (?) \\
\hline Oak & Bears & Ooze of the salt deep & Dew from the still-vex'd Bermoothes & Sea eruption (?) \\
\hline Berries & Urchins & Unwholesome fen & (Bermuda) & Earthquakes (?) \\
\hline Wither'd roots & Toads & Fresh springs & Wind of the north & Ignis fatuus (fool- \\
\hline Acorn & Beetles & Brine pits & Southwest (wind) & ish fire) \\
\hline Bush & Bats & Hard rock & Black cloud & \\
\hline Shrub & Chanticleer (rooster) & Cell & Thunder & \\
\hline Crabs & Fresh brook mussels & Yellow sands & & \\
\hline Pignuts & Apes & Bogs & & \\
\hline Filberts (hazel- & Hedgehogs & Fens & & \\
\hline nuts) & Adders & Flats & & \\
\hline Wheat & Jay & Rock & & \\
\hline Rye & Marmoset & Turfy mountains & & \\
\hline Barley & Scamels & Banks & & \\
\hline Vetches & Sheep & Bosky acres & & \\
\hline Oats & Peacocks & Unshrubb'd down & & \\
\hline Pease & Blind mole & Winding brooks & & \\
\hline Broom groves & Barnacles & Crisp channels & & \\
\hline Vineyards & Bear & Green lands & & \\
\hline Flowers & Owls & Filthy mantled pool & & \\
\hline Tooth'd briers & & Foul lake & & \\
\hline Sharp furzes & & Pool & & \\
\hline Pricking goss & & Lime & & \\
\hline \multicolumn{5}{|l|}{ Thorns } \\
\hline \multicolumn{5}{|l|}{ Lime } \\
\hline \multicolumn{5}{|l|}{ Lime grove } \\
\hline Cedar & & & & \\
\hline
\end{tabular}

other geophysical phenomena, such as volcanic activity, and how this can be inferred directly from his verses.

If earthquakes in WS's plays are treated in a short paragraph by Clark (2005), we cannot ignore the proximity of Great Britain to another land of volcanoes - Iceland, a nation with 31 active and extinct volcanoes. As we read in Poole (2011), in the early modern time, an integral part of the debates, discussions and general curiosity about purgatory was its actual location. In analysing the possible implications thereof, Poole argues that an important Icelandic volcano, Mount Hecla, was a prominent site in early modern cartographic representation and was also an important location of the popular geography of the imagination. She also argues that Mount Hecla shimmers through Hamlet as the geographical locus of purgatory - the prison of Hamlet's father's ghost. After all, Hamlet's line "my imaginations are as foul/As Vulcan's stithy" (III.ii.79-80) ${ }^{1}$ is the first example that the Oxford English Dictionary, 3 (OED) cites for

\footnotetext{
${ }^{1}$ Please note that the references to The Tempest and, as in this case, to other Shakespearean plays are cited in the structure of act, scene and line(s). This is a standard citation method used when quoting from Shakespeare's plays.
}

the word "stithy" (a forge, smithy). In the verse, the god is in fact associated with his underground workplace. She continues that the invocation of Vulcan in the line might be specific to Mount Etna, but it could also be tied more generally to the neologism "volcano", a word that the OED cites as having first been used in English in the writing of Samuel Purchas ("A Vulcano or flaming hill, the fire whereof maybe seene... about 100 miles"; Purchas His Pilgrimage, 1613, VIII.xiv.686). The word also appears in John Florio's Italian-English dictionary of 1598 ("a hill that continually burneth and casteth out flame and smoke"; Florio, 1598). Poole (2011) concludes that a volcano very much in evidence in Shakespeare's part of the world in the late 1590s was not so much Mount Etna as it was Mount Hecla, which erupted continuously for 6 months in 1597. Anyway, contemporaries repeatedly equate Mount Etna to Mount Hecla, as it can be inferred from a song composed in 1600 by Thomas Weelkes, one of England's most famed composers of madrigals.

Other interesting hints come from another author as we will see later (Roe, 2011). All this relates to sub-aerial volcanoes. But, considering underwater volcanism is more complicated as we have already remarked, quoting Mer- 
calli (1883). In the following, he emphasized the importance of conducting such studies on the submarine eruptions occurring in the Mediterranean Sea:

Yet, for geology, the study of underwater volcanoes could almost be said to be more important than that of sub-aerials, since, as it is known, the large pile of layers accessible to the geologists' investigation, and which also constitute the soil of our peninsula, is almost entirely of submarine origin. (Mercalli, 1883; translated from Italian by the author)

At the same time, Mercalli supposed that accounts of eruptions occurring in the immense solitude of the seas must be sporadic. The 1846 eruption (to which we refer later in this paper) perhaps would have remained unknown if a captain of a merchant vessel had not accidentally been a spectator. In the Sicilian Channel and all around the coast of southern Italy, volcanic phenomena are also frequent today. Just to mention the most recent example, in November 2002 there was an important degassing event at sea off the coast of Panarea island (Capaccioni et al., 2005). WS may also have used sources of volcanic phenomena occurring at sea. He probably learnt about it from the captains and the sailors he came into contact with, or maybe he read the ship's diary of the English vessels, which is not an absurd idea if we consider that, in the Elizabethan Age, Great Britain had resumed its commercial expansion in the Mediterranean (De Vitiis, 1986). But here we can only speculate, since historical research on volcanic phenomena that occurred at sea in the past have not yet been performed.

The fascination for volcanoes also comes directly from the classics. Volcanic activity was described by Pliny the Younger in the already mentioned letter to Tacitus. A milestone source about the possible effects of volcanism is Plato's Timaeus and Critia. In this work, the philosopher speculates about Atlantis, an island suddenly destroyed by a catastrophic event. For some scholars, Plato took inspiration from the Egyptian records of the Thera (Minoan) eruption (Santorini), while other interesting descriptions come from the Geography of Strabo.

\subsection{Tempests, storms and sea eruptions}

Before going further, we will clarify the difference between sea storms and sea eruptions. The word "tempest" is defined in dictionaries as being a violent storm, with high winds that can be accompanied by rain, hail or snow. It is a word with a Latin origin, and its etymology indicates an evolution from "period of time" to "period of weather" to "bad weather" to "storm". The word evolved to also include a figurative sense of "violent commotion". WS uses the word "tempest" with this double meaning because the tempest is also the turmoil of the characters in a state of temporary and disarming confusion.
In the first scene of the play, we witness the setting of a storm, or at least that is what it seems. Immediately after, already in the second scene of the play, we learn that the storm is the product of Prospero's potent art, and we receive a description of it through the words of Ariel when he reports how he caused the calamity following Prospero's directions. Another description appears on this occasion with $\mathrm{Mi}$ randa witnessing the shipwrecking from the shore (descriptions analysed in Sect. 5.2). The initial fatality is reiterated in the words of some characters during the play.

What happens to the sea during a storm? Its surface is strongly affected by the wind force; in this case, waves are created by the friction between the wind and surface waters and are called wind-driven waves or surface waves. In other words, surface waves are the product of the interaction between the sea and the atmosphere of our planet. The first scene of the play describes the storm with the words typical of a storm, namely thunder and lightning. The boatswain also uses words typical of a windstorm such as "blow", "wind" and "storm". The word "fire", in this description, does not appear once (I.i.).

Other hazardous waves can be the result of underwater disturbances that displace large amounts of water quickly, such as earthquakes, landslides or volcanic eruptions. These types of waves can also cause tsunamis. The main difference, compared to the previous type of waves, is that in this case a great amount of energy released from within the Earth travels up to the surface, displacing water and raising it above the normal sea level.

In particular, during a submarine eruption we observe, as for sub-aerial volcanoes, the rising of super-heated molten rock (magma) along with ash and gas. What happens on the surface of the sea depends on how the water and the magma interact in relation to the depth of the volcano seabed (Németh and Kòsic, 2020). In shallow waters, where water depths are less than $100 \mathrm{~m}$, hydro-volcanic explosions can be violent, but increasing the water depth significantly decreases the explosive energy of the eruptions as the expansion of steam becomes limited (Zimanowski et al., 2003; Clague et al., 2000).

A volcanic eruption produces earthquakes, since the magma exerts pressure until it cracks the rock. As we will see later (Sect. 5.2), in The Tempest the descriptions of the initial fatality in the following verses of the play is fairly different from the initial scene and correspond better to a sea eruption. The reasons why the initial scene of the tempest is different from the description given by Ariel (I.ii.193-206) and in that given by Miranda observing the event from the shore (I.ii.34; see Sect. 5.2) could be only speculated. Maybe putting a sea eruption into scene would have been difficult, or maybe WS wanted to emphasize that the initial catastrophic event was the product of Prospero's magic art, and in doing so, he took inspiration from another natural event that is certainly more impressive, even if simply described by words. 


\section{Shakespeare's locations}

In Fig. 2, the map shows the locations of the Shakespearean works. It is immediately evident that most of the plays are located in the UK and in Italy. Specifically, one-third of the plays is located in Italy. There is a lot of literature about the interest that WS had in the country. He knew so much about it - even in detail - that some recent studies speculated that the works of WS can be studied only in light of his relationship with John Florio (Gerevini, 2008). Two plays are located in Sicily, namely Much Ado about Nothing (Messina) and The Winter's Tale (Sicily).

We believe that The Tempest is also located in Italy, somewhere in the Sicilian sea, even if the official location of the play is simply "an uninhabited island". Almost all of the characters are Italian, and a precise route is indicated in the southern part of Italy (see Fig. 4).

\section{Introducing The Tempest}

The Tempest is the last play credited entirely to WS. It was probably written between 1610 and 1611 and performed for the first time on 1 November 1611 at court. It was published later in the First Folio of 1623, from an edited transcript by Ralph Crane, the scrivener of the King's Men, the theatrical company to which WS belonged for most of his career (for a synopsis, see Fig. 3).

It is a work that is strongly affected by the period in which it was written. In the Elizabethan Age, the emerging scientific disciplines like astronomy, chemistry and physics coexisted with the fashion for occultism, magic, cabalism, astrology and alchemy, which are the two main currents of thought that Bloch defines as "cold" and "hot" (Bloch, 1972). The protagonist is the new Renaissance magus, astrologer and alchemist, the owner of a deep knowledge, who is able to discover the secret processes of nature with the intent to control it. During the reign of James I, when The Tempest was performed for the first time, the interest in occultism had not yet faded away. Nevertheless, we observe a slow decline of the Renaissance magus. John Dee (1527-1608), a mathematician, astronomer, astrologer and occult philosopher, and an advisor of Queen Elizabeth I, was accused of sorcery several times. He died in poverty under the reign of James I. What happened in Dee's lifetime with regards to his "Renaissance Neoplatonism" was - writes Yates (1975) - happening all over Europe, as the Renaissance turned into the darkness of the witch-hunts. However, the occult disciplines contributed to the development of thoughts that reached their climax in the intellectual revolution initiated by Francis Bacon. This English philosopher contributed to the spreading of the scientific method based on experiments and mathematics elaborated by Galileo Galilei, the father of modern science.

The main character of The Tempest, Prospero, as John Dee, is a magician. However, the way Prospero speaks and behaves seems to recall the new empirical method developed to observe nature. He may have been inspired by the astronomer Tycho Brahe and his island/observatory of Uraniborg. WS lived during a remarkably eventful period in terms of celestial drama. There were passages of comets, solar eclipses and, moreover, the appearance of a bright new star in the constellation of Cassiopeia in November 1572. It was so bright that, for several months, it even outshone Venus. It was observed by Digges in England and monitored even more closely in Denmark by astronomer Tycho Brahe. Today the star is named "Tycho's star" (Falk, 2014).

Marnieri (2013) maintains that Prospero is conscious of the new rational science which is becoming the dominating culture of the age. Not only Prospero uses the adjective "rough" when referring to his magic. In addition, commentators remark on the halo of ambiguity that concerns Prospero's books. We learn from his own words that he is a sort of researcher rapt in secret studies (I.ii.72-77). He also mentions Gonzalo's good hearth with respect to his beloved books (I.ii.164-168). But, remarks Marnieri (2013), when he solemnly pronounces his renunciation of magic, he speaks about one "book" he will "drown" (V.i.50-57).

Of no less importance is another role of Prospero. Besides being a father, a duke, a scientist, a magician and a colonizer, Prospero is mainly a director. From this perspective, the island is a stage, and the play becomes also a way to meditate on theatre as a form of art (metatheatre; Knight, 1932; Frye, 1986; Lombardo, 1986). This raises questions of fundamental importance for the text and its performance, since the theatrical representation that the public attends contains and often overlaps the other representation, which is the one staged by Prospero (Lombardo, 2002). From this perspective, we can suppose that it must have been a challenge for WS to convince the audience that the storm was an illusion, especially after the first scene in which the mariners were supposed to enter the scene in wet clothes.

\subsection{The island of The Tempest - the Bermuda hypothesis}

Even if there are geographical indications of how both Prospero and Miranda and then King Alonso of Naples and his crew reached it, the island is a multifaceted place, both in the philosophical-political and geographical-environmental sense. It is the place where the great Renaissance themes are revived, such as the philosophical utopia, the boundaries of human knowledge and the dominion of nature. We recognize the world of the great journeys and of the newly discovered lands. In the relationship between Prospero and Caliban, the savage and deformed slave, we recognize the relationship between England and America, the invaders and the indigenous people (Knight, 1984). It is generally agreed that WS read the essay of Montaigne, titled Of Cannibals, thanks to the translation of John Florio, in which Montaigne compares the "cannibalism" of some indigenous population in Brazil to the "barbarianism" of 16th century Europe (Florio, 1892). 


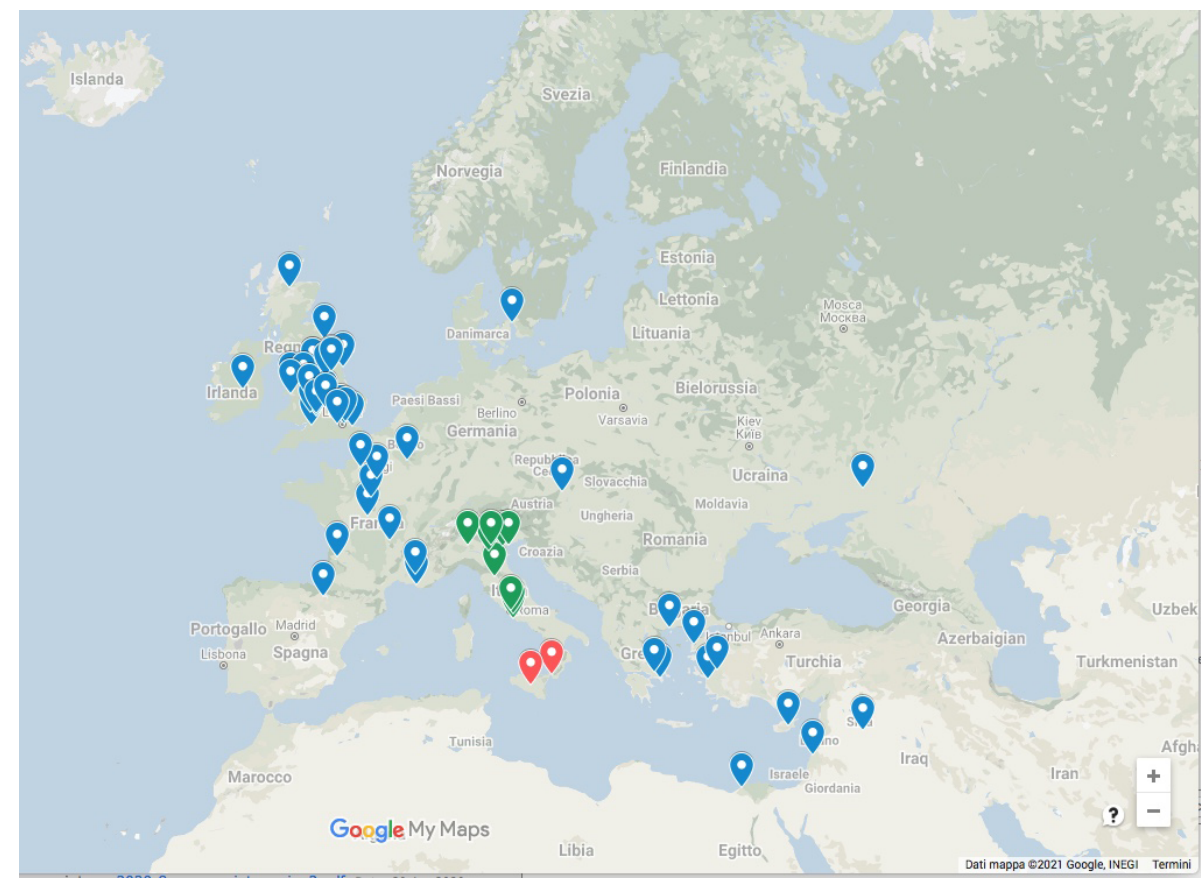

Figure 2. Shakespeare's locations. A map generated with $\odot$ Google Maps by the author. The icons in green and red indicate the plays located in Italy, with those in red referring to the ones based in Sicily. (C) 2020 Google.

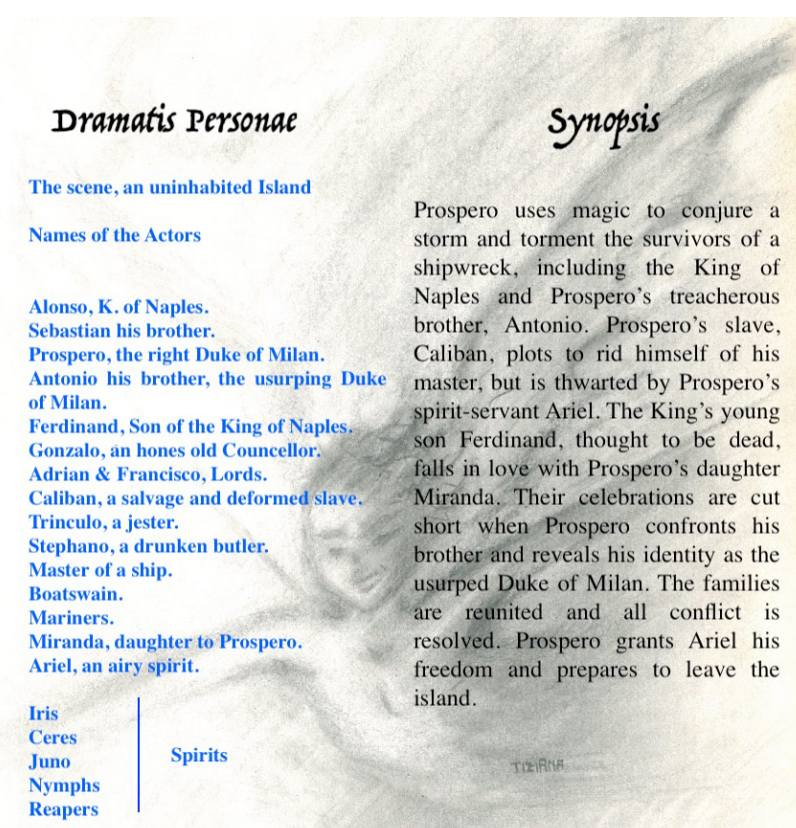

Figure 3. Dramatis personae from Shakespeare (1986). Synopsis source: https://www.shakespeare.org.uk/ (last access: 3 March 2021). In the background, Ariel, drawn by the author, can be seen.
If we think of the philosophical and political aspects, as described above, we can certainly agree that WS used sources to become more acquainted with the New World. It is widely accepted that he used the Bermuda pamphlets, a series of narratives about a wreck that occurred during an expedition to colonize Virginia, as a source for the play. In particular, he used A true repertory of the wreck and Redemption of Sir Thomas Gates Knight, which is a letter Strachey (1625) wrote to an unidentified woman in the English Court. In the letter, Strachey (1625) reports on the 1609 shipwreck on the uninhabited island of Bermuda with the colonial ship Sea Venture, which was caught in a hurricane while sailing to Virginia. Despite the fact that the ship was run aground off the coast of the island, the crew were stranded on it for almost a year before completing the voyage to Virginia.

Some commentators find it difficult to accept that WS could have had access to confidential material reporting on a wreck near Virginia, especially when the English Court was so intent on organizing expeditions to colonize new lands. The letter was, in fact, published many years later in 1625 . Nevertheless, the letter circulated in an informal way, and a copy was found in 1616, the year he died, among the belongings of Hakluyt, a leading adventurer and a member of the Virginia Company's counsel (Gerevini, 2008).

\subsection{Echoes of the Bermuda hypothesis in The Tempest}

After reading the Strachey's (1625) letter, we can easily find echoes of the faraway, transoceanic lands inhabited by spir- 
its and devils in the play. The Tempest eventually used the atmosphere created by the collective imagery concerning these lands that were considered, wrongly according to Strachey (1625), uninhabitable, according to the following:

And hereby, also, I hope to deliver the world from a foul and general error, it being counted of most that they can be no habitation for men, but rather given over to devils and wicked spirits; whereas indeed we find them now by experience to be as habitable and commodious as most countries of the same climate and situation, insomuch as if the entrance into them were as easy as the place itself is contenting, it had long ere this been inhabited as well as other islands". (Strachey, 1625)

Strachey (1625) then describes the nature of the soil, which is one and the same. "The mold dark, red, sandy, dry and uncapable, I believe, of our commodities or fruits" (Strachey, 1625). He also writes "there is not through the whole islands either champaign grounds, valleys or fresh rivers" (Strachey, 1625). Then, he describes the flora as mainly being palm trees, cedar and prickly pear and also emphasizes that there were neither rivers nor springs of fresh water. The only water to be found in the ground is that which comes from the rain, as he explains in the following:

When we came first we digged and found certain gushings and soft bubblings, which being either in bottoms or on the side of hanging ground, were only fed with rain water, which nevertheless soon sinketh into the earth and vanisheth away, or emptieth itself out of sight into the sea, without any channel above or upon the superficies of the earth". (Strachey 1625)

He finally describes a very rich fauna, especially concerning fish.

Despite the atmosphere previously described, none of the ecological traits described in Strachey's letter can be found on Prospero's island, where there is no indication of tropical vegetation. Instead, trees typical of temperate climates are described, such as oak, pine, wild apple trees, kernels, as well as bushes that produce berries (Brazzelli, 2009). Caliban refers to the fertile areas of the island. Speaking to Stefano and Trinculo, he says "I'll show thee every fertile inch o' th' island" (II.ii.148), and he also mentions the springs of fresh water, saying "I'll show thee the best springs" (II.ii.169). From his early interaction with Prospero, we learn that the island has different type of waters, namely "fresh spring" and "brine-pits". The multiple references to rivers and ponds, including a "foul lake" (IV.i.183) and brambles ("briars") and other thorny bushes, allow us to identify a real ecology of the island. The tree in which Ariel has been imprisoned for 12 years before being released from Prospero, is a pine. "Line trees" (V.i.10), which are not tropical trees, protect the entrance of the cave, the home of Prospero, from the weather.
We are also able to identify the geology of the island (Fitz, 1975). We know that the coast is cut by coves or nooks, since Ariel feels obliged to explain to Prospero in just which nook he chose to hide the ship (I.ii.226-29). We know that there are banks, since Ferdinand sits on one to weep (I.ii.389-90). We know from Ariel that the sands are yellow (I.ii.376). We know that there are large rocks with caves in them, for Caliban lives in one of them (I.ii.389-90), and Stefano hides his stolen liquor in another (II.ii.137-38). There are streams and ponds; some fresh (I.ii.339, II.ii.164 and II.ii.75) and some polluted (IV.i.182).

From what we have described until now, we can for sure assert that the island of The Tempest it is not a tropical island. There are not even any palm trees, which, Fitz (1975) emphasizes, are the prime requirements for a modern tropical island, although Shakespeare speaks of palm trees in other plays.

\subsection{Placing the island in a Mediterranean context}

If Ariel (I.ii.229) is said to bring his master the "dew / From the still-vexed Bermudas", then the "south-west wind" that Caliban invokes against Prospero and Miranda (I.ii.320-325) is the "libeccio", which is a typical Mediterranean wind. There are also several occasions on which we can literally "smell" the island in the play, with typical smells of volcanoes being described as in the following conversation (II.i.45-7):

$A d r$. The air breathes upon us here most sweetly

Seb. As if it had lungs, and rotten ones

Ant. Or as "twere perfum'd by a fen"

An important source of The Tempest is Virgil's Aeneid. The Court Party follows a route very similar to that of Aeneas, who travelled from Tunis (Old Carthage) in North Africa to Naples, near Cumae, where Aeneas meets the Sibyl (see Fig. 4 for Aeneas' route). In an apparently aimless conversation among Gonzalo, Alonzo and Sebastian, Gonzalo insists on identifying Carthage with Tunis, and the other two insist on repeating the name of Aeneas and Dido (II.i.71-87).

Adr. Tunis was never grac'd before with such a

Paragon to their Queen

Gon. Not since widow Dido's time

Ant. Widow! A pox o' that! How came that

Widow in? Widow Dido!

Seb. What if he had said "widower Aeneas" too?

Good Lord, how you take it?

Adr. "Widow Dido" said you? You make me

Study of that: she was of Carthage, not of Tunis

Gon. This Tunis, sir, was Carthage. 


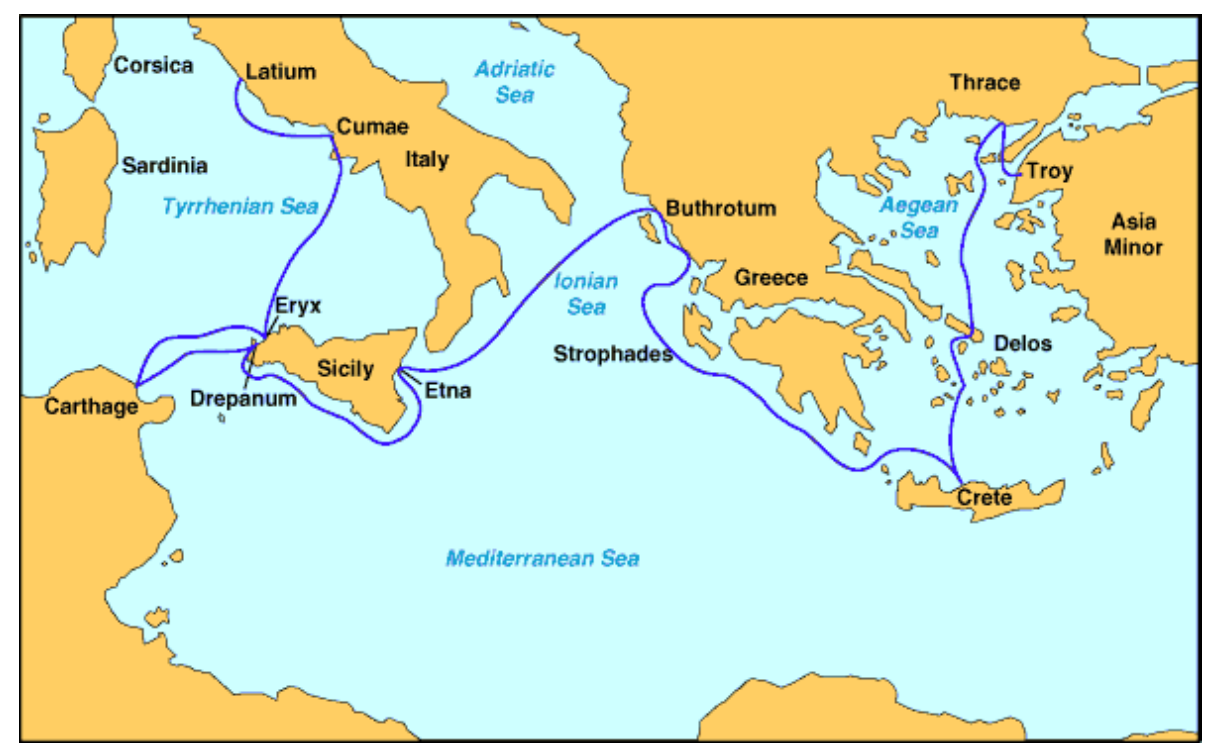

Figure 4. Map of Aeneas's journey. Source: https://faculty.gvsu.edu/websterm/Aeneid.htm (last access: 3 March 2021).

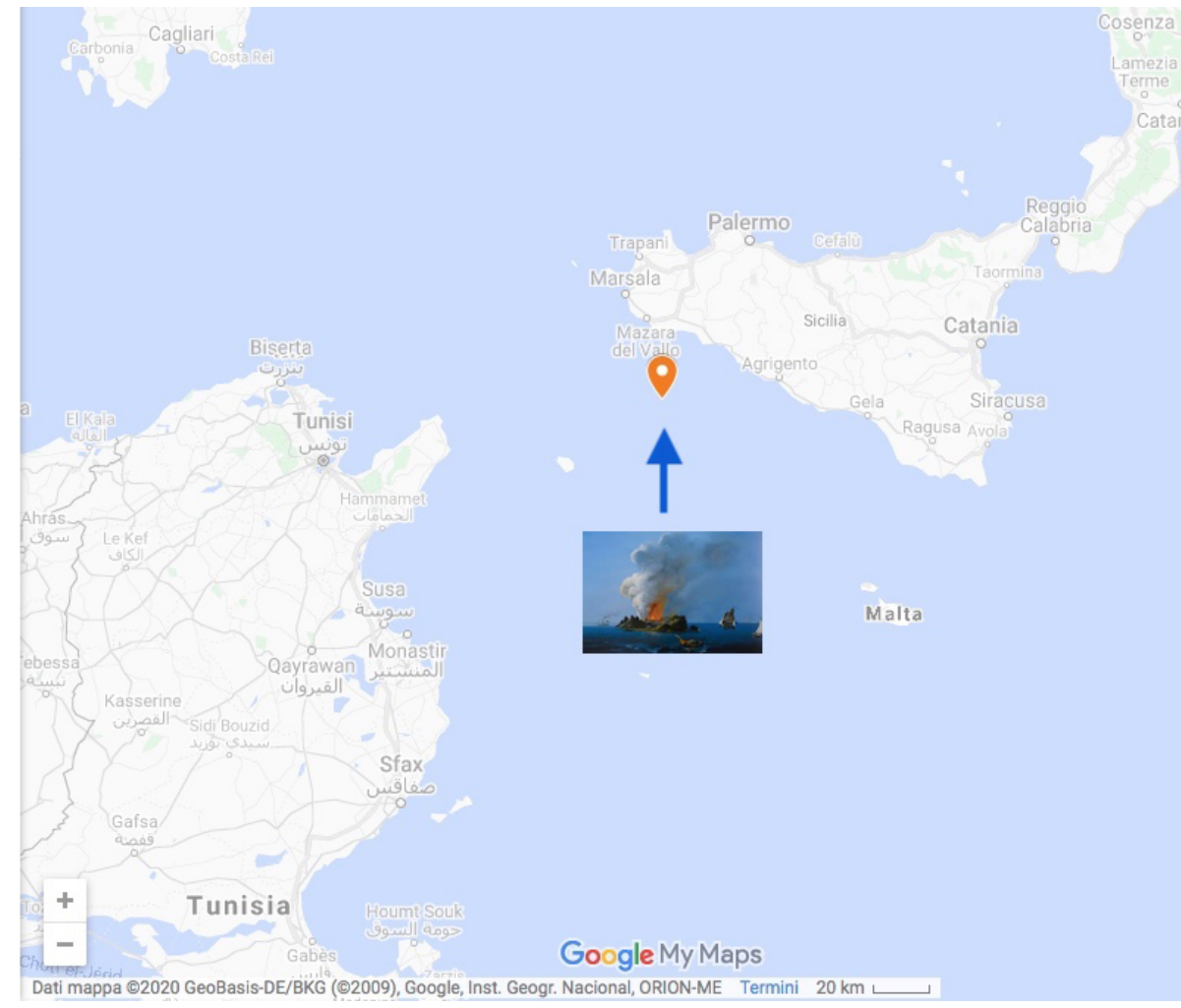

Figure 5. Location of the Ferdinandea island. The island is just $8 \mathrm{~m}$ below sea level and about $50 \mathrm{~km}$ from the shore. The map was generated by the author using Google maps. Figure 1 is shown in the inset. (C) 2020 Google Maps.

Still (1921) states that WS accentuated the importance of this reference to Dido with the ignorance of the dispute, while the question of Antonio, "How come that widow in?", draws the attention to the parallel between the experience of the Court Party and that of Aeneas in Book IV of the Aeneid (Kott and Miedzyrzecka, 1977).

As in the first scene of the play, a storm surprises the Court Party while they are navigating the journey from Tunis to Naples. As we can see in the map (Fig. 4), the first tract 
of the sea is the Sicilian Channel. The hazard of the Sicilian sea has been known since ancient times. In his journey to Italy, Aeneas was advised by Eleno of Burtroto to avoid Scylla and Charybdis. He did so, and after having been near Etna, Aeneas reached Eryx (Erice, in the province of Trapani), where his father Anchises died. He, then, decided to go back to Carthage. During the trip, Juno, who hated the Trojans, provoked a tempest against the fleet (Aeneid I; 81222; Kline, 2002).

In the Acts of the Apostles, Paul of Tarsus, persecuted by the Jews and imprisoned, asked, as a Roman citizen, to be tried in Rome. Under the governor Porcius Festus, he was sent in Rome by sea. His boat shipwrecked and the crew reached Malta (Acts of the Apostles; 27, 1-36; Gabb, 2018). Echoes of this shipwreck can be found in Prospero's account on the tempest to Miranda when he says, "No, not so much perdition as a hair" (I.ii.30), and this was repeated then by Ariel, who reported to Prospero that "Not a hair perish'd" (I.ii.219).

Following Aeneas' route, some commentators identify the islands of The Tempest with Pantelleria. Others search for the island along the North African coast, associating it with the islands of Lampedusa or Malta, crossing the itinerary of the Court Party with the events of Sycorax, who arrived on the island from Algiers (Kott, 1974). More recently, Roe (2011) advanced the hypothesis that the island is in the Tyrrhenian Sea in the Aeolian archipelago. Roe (2011) even identified the island of Vulcano as being the possible location of the play. He maintains that Vulcano, as Stromboli, possesses an active volcano (Roe, 2011). It is the Gran Cratere, or La Fossa di Vulcano, and is especially noxious and deadly. That is why no one felt confident enough to live permanently on the island until fairly recently. With respect to The Tempest, Roe (2011) writes in particular about the "hot mud pools" to be found in Porto Levante in Vulcanello, a peninsula of Vulcano. The largest of the pools is impressive, with carbon dioxide and sulfur dioxide effervescing through the muddy mixture of mineral sludge. The brownish goo bubbles and steams and stinks mightily. The allusion to this hot mud pool is in The Tempest (IV.i.181-184), when Ariel explains to Prospero how he settled the three men, Caliban, Stephano and Trinculo, to thwart a conspiracy against him.

\section{Ari.... At last I left them}

I'th filthy mantled pool beyond your cell,

There dancing up to their chins, that the foul lake

O'erstunk their feet.

These verses are emphasized later by the entry of the three men into the scene, soaking wet with the waters of "the filthymantled pool... the foul lake" and stinking to high heaven (IV.i.199-200).

Trin. I do smell all horse-piss; at which my nose is in great indignation.
The setting, portrayed through the words of Trinculo, Stephano and Ariel, "foul lake", "horse piss", "filthy pool", concludes Roe (2011), describes exactly the stinking, bubbling, hot mud pool of Vulcano. Roe (2011) also explains that Ariel defines the mud pool with the words "filthy mantled", and at the time of WS, Vulcano's hot mud would have been "mantled", that is, covered by a floating crust of dry sulfur, and it would have been covered throughout the entire year. This curious natural phenomenon occurs when a bright yellow particulate of sulfur, drifting down from the crater above, collects on the mud pool's surface. We can imagine that the yellow dust remained untouched on much of the rim and slopes of the Gran Cratere, as it did on the hot mud pool in the playwright's day. It can, therefore, be concluded that the "yellow sands" that the airy spirit sings about in the play ("come into these yellow sands"; I.ii.378-381), refer to the colour of the sulfur.

Roe (2011) identifies further evidence in the flora and in the fauna, also giving an explanation for the word "scamels", which has always remained mysterious for commentators (II.ii.184-185).

\section{Cal. ... sometimes I'll get the \\ young scamels from the rocks.}

"Scamels are migratory marsh and shore birds, sometimes found along the Tyrrhenian seas of Italy and occasionally on beaches in England, or other northern climes" (Roe, 2011). Caliban also mentions the volcano's berries (I.ii.333-334).

Cal. Thou strokedest me, and madest much of me;

Wouldst give me

Water with berries in it.

To Roe (2011), these are clearly the mulberries, which are berries that proliferated in the wild of Vulcano when the playwright visited the island. Even today, an area on Vulcano is referred to locally as "la Contrada del Gelso" (the Mulberry district).

\section{Natural hazards in The Tempest - a fire-based play}

Despite the title, The Tempest is a fire-based play, not only because of the mythological aspect in which all that is suggested by nature becomes a place of expiation, as in Dante's hell and in the mythological literature of the past, but also from a geo-environmental point of view. Counting words, the words "water" and "sea" are repeated 50 times in the text, compared to the 34 occurrences of air and the 15 occurrences of "Earth". The word "fire" does not have the same frequency of use (11 times), but it is present in the denotations and connotations of its essence (Marnieri, 2013).

While water is deprived of its intrinsic power to wet, wrinkle clothes and drown people, the fire becomes so powerful and frightening that it infects the light of reason. Ariel, in the 
form of fire, becomes faster than "Jove's lightnings". The fire is evoked very often in the form of combustion phenomena. To the question of why Prospero is so obsessed with wood, since he always asks Caliban and then Ferdinand to continually carry logs, one may answer "firewood", and this is suggested by Miranda when she comforts the log-bearing prince Ferdinand with the following personification (III.1.19-20; Jensen, 2016):

\section{Mir. When this burns \\ Twill weep for having wearied you}

This idea is also supported by Egan (2006), who argues that Prospero's main activity, since his arrival on the island, has been its deforestation.

Other important geophysical phenomena connected with combustion are St Elmo's fire and ignis fatuus (literally, "foolish fire"). Scholars generally agree that verses (I.ii.96101) in The Tempest evoke St Elmo's fire. This phenomenon is a type of luminous plasma discharge from a pointed object in fields that carry a high voltage. This is often associated with areas of thunderstorms or volcanic ash activity and is completely harmless. A description of it appears also in the Strachey (1625) letter:

Only upon the Thursday night, Sir George Somers, being upon the watch, had an apparition of a little round light, like a faint star, trembling and streaming along with a sparkling blaze, half the height upon the main mast and shooting sometimes from shroud to shroud, 'tempting to settle, as it were, upon any of the four shrouds. And for three or four hours together, or rather more, half the night it kept with us, running sometimes along the main yard to very end and then returning... But upon a sudden, toward the morning watch they lost the sight of it and knew not what way it made.

Strachey (1625) himself remarks that this phenomenon is frequent in the Mediterranean Sea. St Elmo's fire takes its name from St Elmo (St Erasmus, a martyred bishop of Italy, who died in $304 \mathrm{CE}$ ). He was adopted by the sailors of the Mediterranean as their patron saint. The phenomenon was familiar to the ancient Greeks, and Pliny the Elder mentions it in his Natural History. When it appeared as a single flame, it was the Helen of Troy flame and an omen of ill luck. As a doubled flame, it was called Castor and Pollux, the guardian of sailors among the classical gods and, therefore, a good sign. Another description of St Elmo's fire appears in Hakluyt's Divers Voyages. It runs as follows:

I do remember that in great and boisterous storme of this foul weather, in the night, there came upon the toppe of our maine yarde and maine maste, a certain little light, much like unto the light of a little candle, which the Spaniards called the CuerpoSanto, and said it was St Elmo, whom they take to be the aduocate of sailers... . This light continued aboord our ship abouth three hours, flying from maste to maste, and from top to top; and sometimes it would be in two or three places at once. (Hakluyt, quoted by Clark, 2005)

The other interesting phenomenon is the ignis fatuus (in the popular culture it is known as the jack-o'-lantern or willo'-the wisp), which is “a phosphorescent light seen in the air over marshy places, supposed to be caused by the evolution and spontaneous combustion of some highly inflammable gas" (Fun and Wagall's New Standard Dictionary; cited in Clark, 2005). Stephano mentions it when talking about Ariel to Caliban, saying the following:

Steph. Monster, your fairy, which you say is a harmless fairy, has done little better that play the Jack with us. . (IV.i.197-198)

Clark affirms that WS, perhaps, believed that the ignis fatuus and St Elmo's fire were the same thing or had a similar cause, since he makes Ariel impersonate both phenomena. To us, WS was adding wonder to wonder by exploiting the powerful imagery instilled by the use of fire.

\subsection{A tempest or a sea eruption?}

Until now, we have collected evidence that The Tempest was inspired by the Mediterranean Sea. But when does the tempest take place in the play? We are able to learn the time in which the tempest takes place because, after having reported on the tempest performed, Prospero asks Ariel about the time.

Pros. Ariel, thy charge

Exactly is perform'd: but there is more work. What is the

time o'th' day?

Ari. Past the mid season.

Pros. At least two glasses. The time 'twixt six and now

Must by us both be spent most preciously. (I.ii.238-241)

Thus, the tempest occurs during the day and not at night. But, as we read in the previous quotes about St Elmo's fire, the phenomenon is visible at night. So, what was WS really describing with Ariel's words?

Ari. I boarded the Kings' ship; now in the beak, Now in the waist, the deck, in every cabin,

I flamed amazement; sometime I'd divide, And burn in many places; on the topmast, The yards and bowsprit, would I flame distinctly Then meet and join. (I.ii.196-201) 
It seems that St Elmo's fire is described only by the movements of Ariel performing the tempest and nothing else. In reading the verses, we do not have the impression of Ariel performing "certain little light, much like unto the light of a little candle" (Hakluyt in Clarke, 2005) or of "a little round light, like a faint star, trembling and streaming along with a sparkling blaze" (Strachey, 1625). On the contrary, the imagery evoked in the verses is powerful and not as evanescent as a St Elmo's fire. In fact, this phenomenon provoked wonder in sailors but not in the sense that they could be injured by it.

Those scholars who do not agree with the Strachey (1625) letter as being a source of the play have suggested other early modern texts as possible sources. Rea (1919) was the first one to propose one of the Colloquia of Desiderius Erasmus, namely Naufragium, which was translated in 1606 by William Burton. More recently, Stritmatter and Kositsky (2009) summed up all the critical issues regarding the New World interpretation of the play. In the final tables (see Appendix A in Stritmatter and Kositsky, 2009), there is a comparison among three possible sources for the storm (i.e. Ariosto's Orlando Furioso in the translation of Barbara Reynolds, Erasmus's Naufragium in the 1606 translation and Strachey's True Reportory). In the last table (Stritmatter and Kositsky, 2009), where the present verses are considered, we can note that the other texts clearly quote the St Elmo's fire (Ariosto) or mythological figures directly connected to them, i.e. Castor and Pollux (Erasmus and Strachey). Instead, in The Tempest, there is not a clear allusion to the phenomenon, nor does WS use a word that lets us imagine that, at a certain point, the fire vanishes. Even if the description of it as being a "ball of fire" in Erasmus can recall Ariel's description, there remains the ambiguity already remarked upon by Rea (1919), i.e. St Elmo's fire appears, in spite of the fact that is early afternoon. Rea (1919) argues that this discrepancy is to be found in Erasmus's narrative, and WS, in following it, does not notice that he has put it at the wrong time of day.

Another neglected aspect concerns the verses (I.ii.201206) that put the whole description into another geomythological context, since the deities recalled here are not Castor and Pollux but Jove and Neptune. In reading the whole of Ariel's description, we even doubt that WS was describing a tempest.

Pros. Hast Thou, spirit,

Perform'd to point the tempest that I bade thee?

Ari. To every article. I boarded the King's ship; now on the beak,

Now in the waist, the deck, in every cabin,

I flam'd amazement: sometime I'd divide,

And burn in many places; on the topmast,

The yards and boresprit, would I flame distinctly,
Then meet and join. Jove's lightning, the precursors

O'th' dreadful thunder-claps, more momentary

And sight-outrunning were not: the fire and cracks

Of sulphurous roaring the most-mighty Neptune

Seem to besiege, and make his bold waves tremble,

Yea, his dread trident shake. (I.ii.193-206)

In particular, Neptune (the Greek Poseidon) is described as being intent on shaking his dreaded trident. In Ariel's words, there is a war between the sky and the sea, where the sea is described as the "most-mighty Neptune". Neptune was also the god of earthquakes. And he was so powerful as to frighten even Hades, the lord of the dead, as we read in book XX of Homer's Iliad (Homer, 2020).

The sire of gods and men thundered from heaven above, while from beneath Poseidon shook the vast earth, and bade the high hills tremble. The spurs and crests of many-fountained Ida quaked, as also the city of the Trojans and the ships of the Achaeans. Hades, king of the realms below, was struck with fear; he sprang panic-stricken from his throne and cried aloud in terror lest Poseidon, lord of the earthquake, should crack the ground over his head, and lay bare his moldy mansions to the sight of mortals and immortals. (XX.54-57)

The importance of this deity in the play is underlined by another circumstance. Caliban is very often described during the play as being half-man and half-fish.

Trin. ... What

have we here? A man or a fish? dead or

Alive? A fish: he smells like a fish; a very

Ancient and fish-like smell ... (II.ii.25-28)

And later again, in the following:

Trin. Wilt thou tell a monstrous lie, being but half a fish

And half a monster? (III.ii.31-33)

There is another Greek god of the sea, Triton, who is the son of Neptune. Triton is represented as a merman with the upper body of a human and the tailed lower body of a fish. He was also depicted as having a conch shell which he would blow like a trumpet. Ovid (Metamorphoses, 1.332335; Melville and Kenney, 1986) describes him as follows:

Triton, sea-hued, his shoulders barnacled

With sea-shell, bade him blow his echoing conch

To bid the rivers, waves and flood retire. 
This is not the first time that WS uses storms in his plays. As Clark (2005) remarks, thunder, lightning, darkness and gales are there because they harmonize with the terror, despair, horror and wickedness inherent in his grim plots and are intended to intensify the dramatic and tragic atmosphere. Often, these are "shipwrecking storms" and losses at sea as in The Tempest, Pericles, Othello and The Winter's Tale (Clark, 2005).

How does WS deal with storms and shipwrecking in the other plays? Do we find in the other descriptions words such as "fire" or adjectives like "sulphurous" or terms connected to earthquakes? We find words as "fire" and "sulphurous" associated with the sky and with storms in Julius Caesar ("But never till to-night, never till now / Did I go through a tempest dropping fire"; I.iii.9-10) and King Lear (“... you sulphurous and thought-executing fire"; III.2.4). And looking at the plays where the storm is associated with shipwrecking, such as Pericles, we find again the use of the adjective "sulphurous" in association with a storm ("Thy nimble sulphurous flashes"; III.i.6), and we find, as in The Tempest, storms being associated with earthquakes ("Our lodging, standing bleak upon the sea / Shook as the earth did quake"; III.ii.14-15).

Nevertheless, in The Tempest the following question arises: how is Neptune evoked here? Is he the god of the sea or as the Earth shaker? And should the word "cracks" remind us of the descriptions reported about Mount Hecla in Shakespearean times? Poole (2011) reports that, in Purchas, we read about an eruption of Mount Hecla in which "after the Earthquake followed a horrible cracke, that if all warlike Ordnace had beene discharged, it had beene nothing to this terrour" (p. 648). The double nature of Neptune was very well known in ancient mythology. Neptune, before being the god of the sea, was conceived with an equine form, so he was a deity originally linked to the Earth. To maintain this double nature, he was also named the "Evvorícusv" in Greek mythology, which literally means the Earth shaker.

Do these verses also evoke earthquakes? When, in the final part of the play, Prospero resumes all the prodigies accomplished thanks to his potent art, not only does he say that he has triggered a war between heaven and Earth, as follows:

Pros.... And 'twixt the green sea and the azured vault

Set roaring war... (V.i.43-44)

Later, he also asserts the following:

$$
\text { Pros. ... The strong-based promontory }
$$

Have I made shake... (V.i.46-47)

In a short paragraph dedicated to earthquakes in Shakespeare, Clark (2005) affirms that he had a limited knowledge of earthquakes and felt his own limitations due to a limited experience of them. Eventually, WS was more interested in the effects of these catastrophic upheavals rather than embarking upon an effort to discover their obscure causes. This is the reason why references in his plays are limited (Clark, 2005). Nevertheless, in The Tempest, references to earthquakes seem not to be allegorical but rather more descriptive of natural phenomena.

\subsection{Volcanism in the Sicilian sea and The Tempest}

What does the sea of Sicily have to be envious about in comparison to the Bermuda triangle? Absolutely nothing. Its hazards have been known since ancient times, as we have already seen in historical accounts from the epics and The Bible, and it is often reported in the news as it is the route used by migrants approaching Italy from Africa. Archaeological and more recent remains found in the deep sea testify to a difficult navigation in dangerous water that is still evident in modern times. This is probably due to the complex geodynamics of Italy and the sea surrounding the peninsula, which resulted from the evolution of the borders between the African and Euro-Asiatic plates. Only recently has the sea floor of the Sicilian sea in the proximity of the Sicilian Channel been the subject of in-depth studies which reveal the complexity of the area (Corti et al., 2006; Falautano et al., 2010; Cavallaro and Coltelli, 2019). Tectonic extension led to an intra-plate rift system characterized by three tectonic faults and a number of underwater edifices, which is evidence of complex volcanictectonic phenomena (Corti et al., 2006; Civile et al., 2015). A list of 105 islands (including major islands, islets, rocks and stacks) recognized by the Sicilian Islands Award (SIA; Muscarella and Baragona, 2017) is also an indicator of the complex geodynamics of the area.

Sea volcanism in shallow water, not so far from the south of the Sicilian coast (at a distance of $50 \mathrm{~km}$ ), has been well documented on the occasion of the emergence of the Ferdinandea island in 1831 (Figs. 1 and 5; see Fig. 6 for the complexity of the seabed in this area). This has led to monitoring, since 1883 , by the Italian Navy Hydrographic Institute. Recent hydrographic campaigns have located the most superficial point of the old volcanic building at a depth of $9 \mathrm{~m}$. This is a potential hazard for vessels (Sinapi et al., 2017). This represents the only well-documented volcanic event that has occurred in the area; other volcanic activities were uncertainly reported in the surroundings of Graham Bank during the first Punic war (264-241 BC) (Guidoboni et al., 2002; Bottari et al., 2009) and in 1632, 1833 and 1863 (Antonoli et al., 1994; Falzone et al., 2009). Moreover, numerous episodes of strong gas releases in the Graham Bank area were observed in 1816 (Mercalli, 1883), 1845, 1942 and, more recently, in 2003 (Cavallaro and Coltelli, 2019). In 2006, following the directions of Mercalli reporting on the 18 June 1845 sea eruption episode that occurred in the proximity of the Graham Bank, a sea expedition has revealed a huge undersea volcanic complex, which is more or less the size of Mount Etna (Macaluso, 2016). 


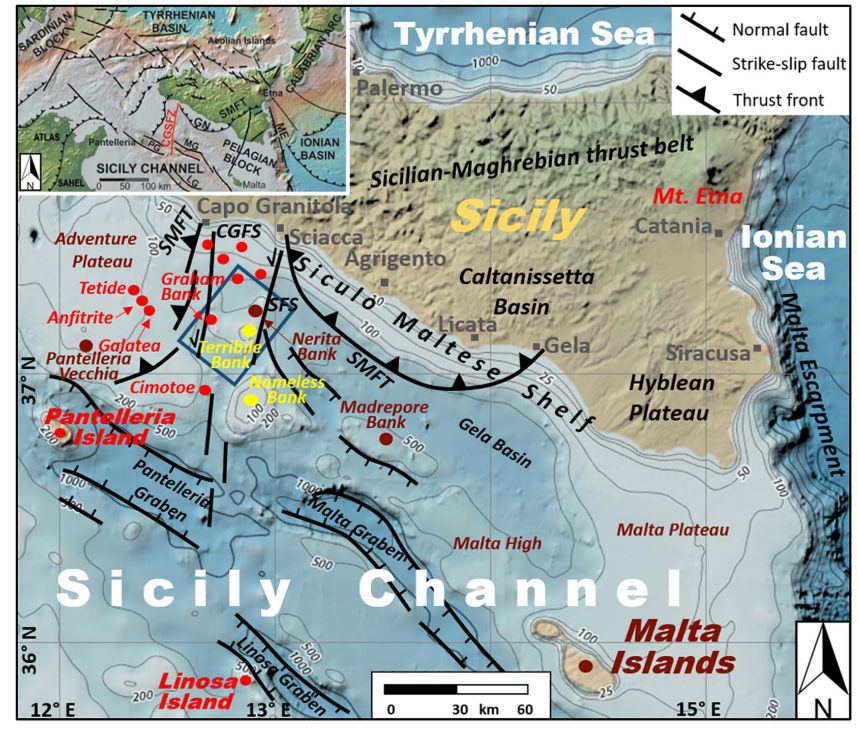

Figure 6. Shaded relief bathymetric map of the northern portion of the Sicilian Channel (from the GEBCO, General Bathymetric Chart of the Oceans, Digital Atlas). The red, brown and yellow circles indicate the location of the volcanic centres, sedimentary banks and sedimentary banks with scattered volcanic manifestations on top (from Cavallaro and Coltelli, 2019).

As we have already said, a thorough study of how many volcanic episodes occurred in the past in the Sicilian sea has never been performed. We have also reported Mercalli's opinion on the importance of such studies (see Sect. 2.1). It is not out of place to speculate that volcanic eruptions at sea in this area may also have occurred during the time of WS. How it would have appeared to those navigating the area is well described by the already quoted 18 June 1845 episode in Mercalli, which we report here in full:

On 18 June 1845 at about 21:00, the English vessel Victory, at $36^{\circ} 44^{\prime} 36^{\prime \prime}$ lat., $13^{\circ} 44^{\prime} 36^{\prime \prime}$ long., was violently shaken, and its two masts were suddenly overturned as under the effect of a terrible tempest, even if in that moment the weather was calm. Suddenly, sulfurous exhalations spread over the air so intense that the crew was almost unable to breathe. The vessel was a bit injured but moved away, and from far away, the travellers saw three huge fireballs coming up from the sea, and the phenomenon was visible for $6 \mathrm{~min}$. (Mercalli, 1883, translated from Italian by the author)

In our view, this description is not so different from the tempest described by Ariel's words (I.ii.193-206), previously analysed, which describe a situation in which a storm occurs, but it is not raining. "The sky, it seems, would pour down stinking pitch," says Miranda to Prospero after having witnessed the tempest from the shore (I.ii.3-4; in this case, the word "stinking" could recall to us the sulfurous exhala- tion of the previous description). Additionally, according to Ariel, the crew do not become wet ("On their sustaining garments not a blemish, but fresher than before"; I.ii.218-219). The fire blazes in different places as the three huge fireballs, as in the description reported in Mercalli.

\section{Ari. I'd divide}

And burn in many places; on the topmast,

The yards and boresprit, would flame distinctly, then meet and join ... (I.ii.198-201)

Moreover, words related to the wind, as in the first scene, are completely missing.

A possible ancient source for The Tempest is the Geography of Strabo, which reports on an episode from the Aeolian Islands in the Tyrrhenian Sea. Volcanism in this area is very well studied, and even recently, in the proximity of Basiluzzo, scientists have discovered what they have called a "smoking land" (Esposito et al., 2018). In the following, Strabo describes sea volcanism between Vulcano and Panarea:

Again, many times flames have been observed running over the surface of the sea round about the islands, when some passage had been opened up from the cavities down in the depth of earth and the fire had forced its way to the outside. Poseidonius says that within his own recollection, one morning at daybreak, about the time of summer solstice, the sea between Hiera (Vulcano) and Euonymus (Panarea) was seen raised to an enormous height, and by a sustained blast remained puffed up for a considerable time, and then subsided; and when those who had the hardihood to sail up to it saw dead fish driven by the current, and some of the men were stricken ill because of the heath and stench, they took flight; one of the boats, however, approaching more closely lost some of its occupants and barely escaped to Lipara with the rest, who would at times become senseless like epileptics, and then afterwards would recur to their proper reasoning faculties. (Strabo's Geography; 6.2.11; Jones, 1924)

In The Tempest, the event occurring out at sea, besides being described by Ariel to Prospero in the verses already quoted, is also witnessed by Miranda from the shore. She clearly says, in the following:

Mir. The sky, it seems, would pour down stinking pitch,

But that the sea, mounting to th' welking's check,

Dashes the fire out ... (I.ii.3-4)

The words recall Strabo's description ("the sea between Hiera (Vulcano) and Euonymus (Panarea) was seen raised to 
an enormous height"). In the excerpt quoted, Strabo also reports on the effects of gas inhalation, which are frequently described in local mythology. The effects of gas inhalation are also reported in The Tempest when those characters surprised by the tempest are described by Ariel (I.ii.206-210).

Pros. My brave spirit!

Who was so firm, so constant, that this coil

Would not infect his reason?

Ari. Not a soul

But felt a fever of the mad, and play'd

Some tricks of desperation.

Did Shakespeare have access to Strabo? It is not absurd to think that the Geography of Strabo circulated at the time of Shakespeare. The importance of geographical studies in early modern England is also underlined in an article (Cormack, 1998). In particular, Strabo's portrait is shown on the title page of a printed commonplace book.

\subsection{The Tempest in the light of geo-mythology}

WS's familiarity with volcanism in the Mediterranean is also supported by the mythology present in the play. In this sense, we may consider WS a further witness to volcanic phenomena taking place in the Mediterranean.

The already quoted gas inhalation is present in Mediterranean mythology and describes the activities of the Pythia, the priestess at Delphi in Greece. The oracle at Delphi appears in The Winter's Tale, a play contemporary to The Tempest which was written between 1609 and 1611. Geologists and toxicologists have argued that the trance-like state of the priestess, the oracle at Delphi, was not just fantasy (Piccardi, 2000; Spiller et al., 2002). One may also think that Sybil, in Cumae where Aeneas stopped over for prophecies during his trip to Rome, may have prophesied under the effect of gas inhalation. The philosophers of the time (Sophocles, Strabo and Virgil) report of an oracle of the dead in the Phlegraean Fields, near Lake Avernus (around Naples, Italy), which is a very active volcanic area with sulfur vents and boiling springs. Sibyl, a prophetess, was considered to be the bridge between the living and the dead. The places evoked in The Tempest through the route of Aeneas and the Court Party are very often associated with hell because of the volcanism. Lake Avernus was considered one of the passages to hell, as was the Etna. Eventually, Sicily was considered, due to its volcanism, to be the land of the devils, comparable to the Bermuda islands (I.ii213-215).

Ari.... the King's son, Ferdinand,

With hair up-staring, then like reeds, not hair, -

Was the first man that leap'd; cried, 'hell is empty,

And all the devils are here'.
In Act IV, scene i, to celebrate the marriage between Ferdinand and Miranda, Prospero put a masque into play, where the protagonist is Ceres (the Greek Demeter), whose daughter was raped by Pluto, the king of hell. Was this myth imported by Greece or was it conceived directly in Sicily? Classical sources such as Diodorus Siculus, Cicero and Ovid place the myth in Enna in Sicily. Near Enna there is a lake, Pergusa, that is believed to be the place where Pluto raped Proserpina.

Not far from Henna's walls there is a lake, Pergus by name, its waters deep and still; it hears the music of the choiring swans as sweet as on Caystros' gliding stream. Woods crown the waters, ringing every side, their leaves like awnings barring the sun's beams. The boughs give cooling shade, the watered grass is gay with spangled flowers of every hue, and always it is spring. Here Proserpina [Persephone] was playing in a glade and picking flowers, pansies and lilies, with a child's delight, filling her basket and her lap to gather more than the other girls, when, in a trice, Dis [Hades] saw her, loved her, carried her away-love leapt in such a hurry! (Ovid, Metamorphoses, 5.462; Melville and Kenney, 1986).

This myth is associated with the idea of death and rebirth, not only in terms of the succession of the seasons but also with the destruction provoked by volcanic eruptions and the following florid rebirth. The most important element associated with Ceres, the goddess of fertility, was grain. Grain and the volcanoes are the two most important elements associated with ancient Sicily. In ancient mythology, Ceres contended for the island with Hephaestus, the god of volcanoes. On that occasion, the nymph Aetna (who gave the name to the most important Sicilian volcano) was the intermediary.

Finally, Ariel, disguised as a harpy, interrupts the scene of the banquet (III.iii). Aeneas meets harpies in the Strofades islands in Greece. Virgil put these figures in the lobby of the hell.

\section{Conclusion}

In the present paper, we collected evidence that WS took inspiration from the Mediterranean to portray the "unknown island" of The Tempest. We have also suggested that some verses of The Tempest, rather than describing a storm, describe phenomena of volcanic origin. WS could, therefore, have been inspired by accounts and sources describing Sicily and the Sicilian sea. Its hazards have been known since ancient times. The sea was renown for the "strange things" happening in it, such as balls of fire, sulfurous exhalations, dead fish and violent storms occurring when the weather was calm. How amazing these phenomena must have seemed to people navigating these waters - especially in the past, when the 
study of volcanoes was taking its first steps. WS, who used natural phenomena to intensify the most dramatic moments of his plot, knew those seas that the sailors dreaded. We do not know if WS ever visited these places. As we have reviewed, he used ancient sources, such as Virgil's Aeneid, The Bible, and the Geography of Strabo. But he may also have used as yet unknown sources, such as the ship's diary of the vessels navigating those seas. His last play seems to really be a portrait of Sicily and the sea surrounding the island. It is the land of volcanoes, the land of the tempests of fire and the land of the devils!

Data availability. No data were used in this paper, but all references (as provided in the bibliography) are freely available online and are part of the public domain.

Competing interests. The author declares that there is no conflict of interest.

Special issue statement. This article is part of the special issue "Five years of Earth sciences and art at the EGU (2015-2019)". It is a result of the EGU General Assembly 2019, Vienna, Austria, 7-12 April 2019.

Acknowledgements. This paper is dedicated to the memory of Enzo Boschi, who recently passed away. He was a scientist but also passionate about literature and the arts. Besides making an important contribution to seismological research, he contributed significantly to the development of historical seismology in Italy. The paper is also dedicated to the memory of Alberto Gabriele of the International Centre for Scientific Culture in Erice, Italy. It was there that I saw a picture of the Ferdinandea island for the first time that gave me the idea for the present study. They were both fans of the island.

I am also grateful to R. John Leigh, one anonymous referee and the editor, Jutta Thielen-del Pozo, for the precious suggestions and the fruitful discussion that helped to significantly improve this paper.

Review statement. This paper was edited by Jutta Thielen-del Pozo and reviewed by R. John Leigh and one anonymous referee.

\section{References}

Antonoli, F., Donadio, C., Ferranti, L., Margottini, C., and De Vita, A.: Il Banco Graham: storia, sismica storica, petrologia e geomorfologia subacquea. Nascita e scomparsa del vulcano sommerso nel Canale di Sicilia, Mem. Descr. Carta Geol. d'It. 52, 99-102, 1994.

Bloch, E.: Vorlesungen zur Philosophie der Renaissance, Suhrkamp Taschenbuch, Frankfurt, Germany, 1972.
Boschi E., Gasperini P., Smriglio G., Valensise G.: The new "Catalogue of Strong Italian Earthquakes", Ann. Geophys.-Italy, 18, 5-6, https://doi.org/10.4401/ag-4072, 1995.

Bottari, C., Stiros, S. C., and Teramo, A.: Archaeological evidence for destructive earthquakes in Sicily between 400 B.C. and A.D. 600, Geoarchaeology 24, 147-175, https://doi.org/10.1002/gea.20260, 2009.

Brazzelli, N.: An Island Nowhere, L'isola della Tempesta tra geografia e immaginazione, Annali della Facoltà di lettere e Filosofia dell'Università degli studi di Milano LXII, 1, 131-153, http://hdl.handle.net/2434/56358 (last access: 3 March 2021), 2009.

Capaccioni B., Tassi F., Vaselli O., Tedesco D., Rossi P.L.,: The November 2002 degassing event at Panarea Island (Italy): five months of geochemical monitoring, Ann. Geophys.-Italy 48, 45, 2005.

Cavallaro, D. and Coltelli, M.: The Graham Volcanic Field Offshore Southwestern Sicily (Italy) Revealed by High-Resolution Seafloor Mapping and ROV Images, Front. Earth Sci., 7, 311, https://doi.org/10.3389/feart.2019.00311, 2019

Chiari, S.: Shakespeare's representation of weather, climate and environment, The early modern "fated sky", Edinburgh University Press, Edinburgh, UK, 2019.

Civile, D., Lodolo, E., Zecchin, M., Avraham, Z. B., Baradello, L., Accettella, D., Cova, A., and Caffau, M.: The lost Adventure Archipelago (Sicilian Channel, Mediterranean Sea): Morphobathymetry and Late Quaternary palaeogeographic evolution", Global Planet. Change, 125, 36-47, 2015.

Clague, D. A., Moore, J. G., Reynolds, J. R.: Formation of submarine flat-topped volcanic cones in Hawai'i, Bull. Volc., 62, 214 233, https://doi.org/10.1007/s004450000088, 2000.

Clark, C.: Shakespeare and Science, Uni. Press of the Pacific, Forest Grove, OR, USA, 2005.

Cormack, L. B.: Britannia rules the waves? Images of empire in Elizabethan England, Early Modern Literary Studies 4.2/Special Issue 310.1-20, available at: http://purl.oclc.org/emls/04-2/ cormbrit.htm (last access: 14 December 2020), 1998.

Corti, G., Cuffaro, M., Doglioni, C., Innocenti F., Manetti, P.: Coexisting geodynamic processes in the Sicily Channel, Geol. S. Am S., 409, 83-96, 2006.

De Vitiis, G. P.: Il Mediterraneo nel XVII secolo: L'espansione commerciale inglese e l'Italia., Studi Storici, 27, 109-148, 1986.

Egan, G.: Green Shakespeare: from Ecopolitics to Ecocriticism, Routeledge, New York, USA, 2006.

Esposito, V., Andaloro, F., Canese, S., Bortoluzzi, G., Bo, M., Di Bella, M., Italiano, F., Sabatino, G. Battaglia, P., Consoli, P., Giordano, P., Spagnoli, F., La Cono, V., Yakimov M. M., Scotti, G., and Romeo, T.: Exceptional discovery of a shallow-water hydrothermal site in the SW area of Basiluzzo islet (Aeolian archipelago, South Tyrrhenian Sea): An environment to preserve, PLos One, 1, e0190710, https://doi.org/10.1371/journal.pone.0190710, 2018.

Falautano, G., Falzone, G., Lanzafame, G., Macaluso, D., Niosi, M., and Rossi, P.: Primi Tentativi di monitoraggio dei resti sottomarini dell'eruzione che nel 1831 costruì l'Isola Ferdinandea nel Canale di Sicilia, Rapporti tecnici INGV, Rome, Italy, 125, 2010.

Falk, D.: The Science of Shakespeare, Thomas Dunne Books, New York, 2014. 
Falzone, G., Lanzafame, G., and Rossi, P. L.: Il vulcano Ferdinandea nel Canale di Sicilia, Geoitalia, 29, 15-20, 2009.

Fitz, L. T.: The Vocabulary of the Environment in The Tempest, Shakespeare Quarterly, 26, 42-47, 1975.

Florio, J. A: Worlde of Wordes, or Dictionarie of the Italian and English tongues, E. Blount, London, 1598.

Florio, J.: Of the Cannibals in The Essays of Montaigne done into English by J. Florio, 217-231, David Nutt in the Strand, London, UK, 1892.

Frye, N.: The Tempest in N. Frye on Shakespeare, Yale University Press, New Haven and London, London, UK, 1986.

Gabb, S.: Acts of the Apostles, the Centre for Ancient Studies, Deal, Kent England, UK, available at: https://www.seangabb.co. uk/acts-of-the-apostles-greek-latin-english-whole-text/ (last access: 4 March 2021), 2018.

Gerevini, S.: William Shakespeare, ovvero John Florio: un fiorentino alla conquista del mondo Pilgrim Ed., available at: http://www.shakespeareandflorio.net (last access: 3 March 2021), 2008.

Giacomelli, L., Perrotta, A., Scandone, R., and Scarpati C.: The eruption of Vesuvius of $79 \mathrm{AD}$ and its impact on human environment in Pompei, Episodes, 26, 235-238, https://doi.org/10.18814/epiiugs/2003/v26i3/014, 2003.

Guidoboni, E., Comastri, A., and Traina, G.: Catalogue of Ancient Earthquakes inthe Mediterranean area up to 10th century, INGSGA, Bologna, Italy, 1994.

Guidoboni, E., Muggia, A., Marconi, C., and Boschi, E.: A case study in archaeoseismology. The collapses of the Selinunte temples (Southwestern Sicily): two earthquakes identified, Bull. Seismol. Soc. Am., 92, 2961-2982, https://doi.org/10.1785/0120010286, 2002.

Guidoboni, E., Ferrari, G., Tarabusi, G., Sgattoni, G., Comastri, A., Mariotti, D., Ciuccarelli, C., Bianchi M. G., and Valensise, G.: CFTI5Med, the new release of the catalogue of strong earthquakes in Italy and in the Mediterranean area, Sci. Data, 6, 80, https://doi.org/10.1038/s41597-019-0091-9, 2019.

Homer: Iliad, translated by Samuel Butler, available at: https://uh. edu/ cldue/texts/iliad.html, last access: 2 December 2020.

Jensen, R. T.: The roles of trees in Shakespeare, Tolkien, and Atwood, Thesis, University of Oslo, Oslo, Norway, 2016.

Jones, G.: Shakespeare's Storms, Manchester University Press, Manchester, UK, 2016.

Jones, H. L.: Strabo: The Geography, Books 6-14, Harvard University Press, London, UK, available at: https://topostext.org/work/ 144 (last access: 3 March 2021), 1924.

Jones, N. F.: Pliny the Younger's Vesuvius “Letters" (6.16 and 6.20), The Classical World, 95, 31-48, 2001.

Kline, A. S.: Virgil, Aeneid, Poetry in Translation, available at: https://www.poetryintranslation.com/PITBR/Latin/ VirgilAeneidI.php\#anchor_Toc535054292 (last access: 4 March 2021), 2002.

Knight, G. W.: The Shakespearean Tempest, Oxford University Press, London, UK, 1932.

Knight, G. W.: Shakesperian Dimension, Prentice Hall/Harvester Wheatsheaf, Brighton, UK, 1984.

Kott, J.: Shakespeare our contemporary, Norton, New York, USA, 1974.

Kott, J. and Miedzyrzecka, D.: The Tempest, or Repetition, Mosaic, 10, 23-36, 1977.
Lanza, T. and Negrete A.: From myth to earth education and science communication, Geol. Soc. London, 273, 61-66, https://doi.org/10.1144/GSL.SP.2007.273.01.06, 2007.

Leigh, R. J., Casson, J., and Ewald, D.: A Scientific Approach to the Shakespeare Autorship Question, Sage Open, 9, 1-13, https://doi.org/10.1177/2158244018823465, 2019.

Lombardo, A.: Il testo e la sua performance. Per una critica imperfetta, Editori Riuniti, Rome, Italy, 1986.

Lombardo, A.: La grande conchiglia. Due studi su La Tempesta, Bulzoni, Rome, Italy, 2002.

Macaluso, D.: Vulcanesimo sedimentario e ricerca di idrocarburi in mare. La scoperta di un grande pockmark nello stretto di Sicilia, Geologia e Ambiente 2, 2-16, 2016.

Marnieri M. T.: Prospero's Magic and the Role of the Four Elements. A reading of The Tempest, Revistas de Linguas Modernas, 18, 13-44, 2013.

Mazzio, C.: Shakespeare and Science, c. 1600, South Central Review, 26, 1-23, 2009.

Melville, A. D. and Kenney, E. J.: Ovid Metamorphoses, Oxford University Press, New York, USA 1986.

Mercalli, G.: Vulcani e Fenomeni Vulcanici in Italia, La Geologia d'Italia, Milano, Italy, 1883.

Muscarella, C. and Baragona, A.: The endemic fauna of the sicilian islands, Biodiversity Journal, 8, 249-278, 2017.

Nemeth, K. and Kósik, S.: Review of Explosive Hydrovolcanism, Geosciences 10, 44, https://doi.org/10.3390/geosciences10020044, 2020.

Piccardi, L.: Active faulting at Delphi, Greece: Seismotectonic remarks and a hypothesis for the geologic environment of a myth, Geology, 28, 651-654, 2000.

Poole, K.: Supernatural Environments in Shakespeare's England, Space of Demonism, Divinity and Drama, Cambridge University Press, New York, USA, 2011.

Rea, J. D.: A source for the storm in The Tempest, Modern Philology, 17, 279-286. 1919

Roe, P. R.: The Shakespeare Guide to Italy. Retracing the Bard's unknown travels, Harper Perennial Ed., New York, USA, 2011.

Shakespeare, W.: The Tempest, edited by: Kermode, F., The Arden Shakespeare, London, UK, 1986.

Sinapi, L., Lamberti, L. O., Pizzeghello, N. M., and Ivaldi, R.: The Graham Bank: hydrographic features and safety of navigation, Int. Hydrogr. Rev., 15, 7-20, available at: https://journals.lib.unb. ca/index.php/ihr/article/view/25811 (last access: 3 March 2021), 2017.

Spiller, E.: Shakespeare and the Making of Early Modern Science: resituating Prospero's Art, South Central Review, 26, 24-41, 2009.

Spiller, H. A., Hale, J. R., De Boer, J. Z.: The Delphi oracle: a multidisciplinary defence of the gaseous vent theory, J. Clin. Tox., 40, 189-196, 2002.

Still, C.: Shakespeare's Mystery Play: a study of The Tempest, C. Palmer, London, UK, 1921.

Strachey, W.: A true repertory of the wracke and redemption of Sir Thomas Gates Knight; upon and from the Island of the Bermudas, July 15, 1610. Purchase his Pilgrims, 4, IV Willaim Stansby for Henrie Fetherftone, London, UK, 1625.

Stritmatter, R.: "Small Latine and Lesse Greeke", Anatomy of a Misquotation, The Oxfordian, 19, 9-44, available at: https://shakespeareoxfordfellowship.org/wp-content/ 
uploads/TOX19_Stritmatter_Small_Latine.pdf (last access: 4 March 2021), 2017.

Stritmatter, R. and Kositsky, L.: "O Brave New World": "The Tempest" and Peter Martyr's "The Orbe Novo", Questioning Shakespeare, 21, 7-42, 2009.

Vitaliano, D. B.: Legends of the Earth, Their Geologic Origins, Indiana University Press, Bloomington, IN, USA, 1973.

Werth, A.: Shakespeare's "Lesse Greek", The Oxfordian V, 1129, available at: https://politicworm.files.wordpress.com/2009/ 04/werth-lesse-greek-tox022.pdf (last access: 4 March 2021), 2002.
Yates F. A.: Shakespeare's Last Plays: A New Approach, Routledge and Kegan Paul, London, UK, 1975.

Zimanowski, B., Wohletz, K., Dellino, P., and Buttner, R.: The volcanic ash problem, J. Volcanol. Geotherm. Res., 122, 1-5, https://doi.org/10.1016/S0377-0273(02)00471-7, 2003. 